Proceedings of the $2^{\text {nd }}$ International Conference on Climate Change, Vol. 2, Issue 2, 2018, pp. 01-17 Copyright (C) 2018 TIIKM

ISSN 2513-258X online

DOI: https://doi.org/10.17501/2513258X.2018.2201

\title{
CLIMATE EXTREMES AND PRECIPITATION TRENDS IN KELANI RIVER BASIN, SRI LANKA AND IMPACTS ON STREAMFLOW VARIABILITY UNDER CLIMATE CHANGE
}

\author{
K.D.C.R. Dissanayaka ${ }^{1 *}$ and R.L.H.L. Rajapakse ${ }^{1}$ \\ ${ }^{1}$ UMCSAWM, Department of Civil Engineering, University of Moratuwa, Sri Lanka
}

\begin{abstract}
This paper focuses on and analyses the potential hydrological impacts of climate change on the hydrologic regime of Kelani River Basin, Sri Lanka. The basin wide future hydrology is simulated by using downscaled temperature and precipitation outputs from the Canadian Earth System Model - Version 2 (CanESM2) and the Hydrologic Engineering Centre's Hydrologic Modeling System (HEC-HMS). The research further evaluates the long-term behavior and trends of the climate extremes based on the observed historical temperature and precipitation data. The findings suggest that the temperature and precipitation extremes are on the rise while the annual average precipitation in the basin is declining. It is also predicted with the application of statistical downscaling that temperature may rise annually for representative concentration pathways of RCP2.6, RCP4.5 and RCP8.5. A detailed modelling approach is incorporated to Hanwella subwatershed $\left(1799.67 \mathrm{~km}^{2}\right)$ of the Kelani River basin to study the subsequent water resource management options required to ensure sustainable development alternatives with the varying streamflow of the Kelani River basin under the effect of the future (2020's, 2050's and 2080's) rainfall and temperature as impending climate change impacts. The paper reviews the current state of the catchment as well as the suitability of applying the GCM's rather than RCM's to Sri Lanka to assess this river basin, according to monthly, seasonal and annual variations of the climate data. Further, a quantitative analysis of the change of amount of surface water in the selected river basin with respect to the expected variations in precipitation and temperature is also carried out. The findings of this research and overall outcome will be useful in identifying possible sustainable water management scenarios with best management options and mitigation measures like land use and carbon emission management, etc. in a more meaningful manner in the future. This study will set the baseline for commencing and continuing quantitative studies incorporating the behavior of the basinwide climatology and streamflow variability with the use of GCM's to achieve sustainable development goals.
\end{abstract}

Keywords: Climate Change, Climate Extremes, Precipitation Temperature and Streamflow Trends, Statistical Downscaling

\section{Introduction}

Climate change is a crucial issue since the impacts are already visible and disproportionate on various regions around the world. The Earth's climate is changing, and the scientific consensus is not only that human activities have contributed to it significantly, but that the change is far more rapid and dangerous than thought earlier (IPCC, 2007). One of the most relevant and debated aspects of the climate change is to deal with its impacts on the hydrological cycle, and in particular, on the statistical properties and seasonal changes of the precipitation, temperature and runoff and consequently on the discharge in the rivers (Hasson., Lucarini, \& Pascale, 2013). Due to climate change effects, most of the agriculture based economies of the South and South East Asia are facing huge challenges in food security. This extends to the financial systems due to their large dependency on the supplies of freshwater and inadequate integrated water resources management. The variability of rainfall and temperature due to climate change has a possibility to cause extended droughts and more frequent floods, triggering problems with the reservoir storages and resulting in great threat to water 
resources (Lal et al., 2011). As an example, considering future water availability under the warmer climate while planning new water reservoirs should be long sighted, keeping in mind that the required huge investment is comparable to the timescale over which significant changes in hydro-climatology of the region will manifest themselves clearly (Krol, et al., 2000). The South and South East Asia have become hot spots of climate change. It is anticipated that the changes in the hydrological cycle will be quite serious in the region, resulting in-public policy and water resource management problems with potentially serious impacts on its socio economical processes (IPCC, 2013). From 1950's, the concentration of $\mathrm{CO}_{2}$ and other greenhouse gases has been dramatically increasing due to industrialization and related activities (Gebremeskel, \& Li, 2005). This is resulting in increased global warming due to imbalance of the global energy cycle. Further, according to the IPCC 5th Assessment Report on Climate Change (IPCC., 2007), global mean surface temperature is showing a warming trend of $0.85^{\circ} \mathrm{C}$ over the period from $1880-2012$. An insignificant increase of $0.78{ }^{\circ} \mathrm{C}$ was observed between the periods of 2003-2012 with respect to the period 1850-1900. In IPCC (2013), it is stated that the global mean surface temperature is projected to increase for the period of $2081-2100$ by $0.3-1.7^{\circ} \mathrm{C}$, $1.1-2.6^{\circ} \mathrm{C}, 1.4-3.1^{\circ} \mathrm{C}$ and $2.5-4.8^{\circ} \mathrm{C}$ under RCP2.6, RCP4.5, RCP6.0 and RCP8.5 scenarios respectively relative to the period $1986-2005$.

This increasing global warming can disturb the hydrologic cycle of the globe, and can even cause problems related to public health, industrial and municipal water demands, hydro power sector subsequently leading to imbalance of ecosystem (Mahmood, Babel, \& Shaofeng, 2015). The future prediction of the change of the climate is defined based on the GCMs (Global Climate Models) using climate variables such as evaporation, precipitation and temperature. Over the last few decades, the GCMs have become the most advanced and numerically based coupled models which represents the global climate system (Fowler et al., 2007). The application of GCMs at local and regional scales (i.e. the basin and sub-basin scales) to assess the impacts of climate change on the hydrological cycle is problematic due to their mismatch of resolution when downscaling from global scale to local scale (Wilby \& Wigley, 2000) and GCMs cannot give a realistic representation of climate change of local/regional scales due to the parameterization limitations as well. This scale mismatch is overcome by developing downscaling techniques, namely dynamical and statistical downscaling, to make large scale outputs of GCMs applicable to local or regional scales (Wetterhall, Halldin \& Chong-yu Xu, 2004).

The Statistical Downscaling establishes a bridge between the large scale variables of GCMs with the local scale variables like evaporation and precipitation by creating empirical or statistical relationships. This process is computationally inexpensive and much simpler than the dynamical downscaling process (Wetterhall et al., 2008). For the present study, SDSM - Statistical Downscaling Model (Wilby \& Wigley, 2000; Fowler et al., 2007) was used. The main limitation of the statistical downscaling approach is the requirement of historical meteorological data over a long period to establish an empirical and statistical relationship with large scale variables (Mahmood et al., 2015). Statistical downscaling is mainly dependent on the level of the uncertainties of the parent GCM used for the study. The selected model of SDSM is frequently used for downscaling important climate variables like evaporation, precipitation and temperature. The downscaled variables from the parent GCM are used to evaluate the impacts of hydrological cycle under climate change (Wilby et al., 2006). It should be noted that no previous studies have investigated the spatial and temporal future changes in maximum temperature, minimum temperature and precipitation under RCP scenarios of RCP2.6, RCP4.5 and RCP8.5 in the Kelani River basin, the second largest river in Sri Lanka by volume of discharge.

\section{Overview and Present Status of the Kelani River Basin}

\section{Kelani River Basin}

The study region comprises a major river basin situated west of Sri Lanka, namely the Kelani River basin. The hydrological regimes of this basin are unique because the basin features great geographical and climatic diversities due to its latitudinal and longitudinal extent and rapidly varying terrain gradient from upstream to 
downstream. Kelani River that originates from the central hills and flows to the west coast through the capital Colombo city is the second largest river in Sri Lanka by volume of discharge and having a contributory catchment area of $2,314 \mathrm{~km}^{2}$. The river basin is bounded by northern latitudes from $6^{\circ} 47^{\prime}$ to $7^{\circ} 05^{\prime}$ and eastern longitudes from $79^{\circ} 52^{\prime}$ to $80^{\circ} 13^{\prime}$. The river originates approximately at an elevation of 2,250 $\mathrm{m}$ above mean sea level and passes $145 \mathrm{~km}$ through four districts in the country, namely Nuwara-Eliya, Kegalle, Gampaha and Colombo, before it reaches the Indian Ocean. The river basin experiences an average annual rainfall of about $3,450 \mathrm{~mm}$ corresponding to a volume of about 7,860 MCM, out of which a 43\% is discharged in to the sea. The streamflow in the river varies between $600-1,800 \mathrm{~m}^{3} / \mathrm{s}$ during monsoon periods. The catchment of Kelani River basin consists of several tributaries. The upper catchment of the river basin starts from Hanwella gauging station. From the 1970's, the Kelani River is being utilized for producing hydropower using Castlereigh, Laxapana and Maussakalle reservoirs in the upper-most of the river basin (De Silva et al., 2014). Figure 1 shows the precipitation, temperature and streamflow gauging station distribution used for this study. Only the data recorded at Hanwella gauging station was used for streamflow modeling. The Kelani River basin is highly vulnerable to flooding (e.g. May 2016 and 2017) due to its geographic location, terrain and orientations. The upper catchment is mountainous and the lower catchment is almost flat with the entire river basin situated in the wet zone of the country which receives high intensity rainfalls. During the past decades, average maximum and minimum temperatures have slightly increased and a significant variability in average annual precipitation with respect to the mean has been recorded. This would result in severe effects on water resource management in the long run.

\section{Study Area}

Hanwella sub-watershed is the upper catchment of the Kelani River basin. The entire Hanwella sub-watershed has an area of $1,799 \mathrm{~km}^{2}$ and streamflow gauging station is located at a distance of less than $40 \mathrm{~km}$ from the river outfall (Fig. 1). Basin wide areal temperature and rainfall were derived based on Thiessen polygon method. The derived areal temperature was studied for temperature change while the derived areal rainfall was used for streamflow modelling.

\section{Data and Data Resolution}

Daily rainfall data at seven rainfall gauging stations (Fig. 1) were obtained from the Department of Meteorology, Sri Lanka for the period of 1970 - 2015 (45-years). The maximum and minimum temperature data in daily resolution were obtained from the same source for the Colombo and Nuwara-Eliya meteorological stations for the same period of 1970 - 2015. This long term data set was used to analyze the behavior of the precipitation and temperature extremes in the Kelani River basin. Observed daily streamflow data from 19852010 at Hanwella gauging station were obtained from the Department of Irrigation, Sri Lanka for the development of calibrated and validated HEC-HMS model (De Silva et al., 2014). The GCM data of CanESM2 model were downloaded from Canadian Climate Change Modeling and Analysis web portal.

\section{Methodologies, Analysis and Results}

\section{Identification of Extremes and Trends}

In this study, precipitation and temperature were identified as the climate variables. Therefore, to identify the extreme events of precipitation and temperature, the IPCC indices were used (Relslnger \& Pachaurl, 2007). Identifying the extremes of precipitation and temperature are important as these events are often associated with flood hazards, extended droughts and ultimately higher risk of epidemic diseases. Furthermore, the climate extremes are receiving increased attention, because the impacts of climate change are felt most strongly through changes in these events. Yet, the information collected on extreme events is incomplete (Frich et al., 2002) due 
to large areas with scarce or non-existent data coverage. One such area includes parts of Central and South Asia where no long-term digital climatology daily data are readily available.

\section{Extremes of Precipitation}

To evaluate the extremes of precipitation, the long-term $(1970$ - 2015) trends of indices were identified for point rainfall stations used in the present study (Fig 1). The results of trend analysis of extremes of precipitation were tabulated in Table 1, for point rainfall stations, Hanwella sub-watershed and Kelani River basin. According to the results, two out of seven showed an increasing trend in annual total wet-day precipitation (PRCPTOT), namely for Colombo and Pasyala. Only Colombo indicated an increasing trend of 0.297 for annual maximum 5day consecutive precipitation (RX-5day). The result of the trend of annual maximum 1-day precipitation (RX1day) shows that four out of seven have an increasing trend with a maximum of 0.516 for Colombo and -0.471 was the maximum decremental trend for Yatiyanthota.

The trend of consecutive dry day (CDD) was decreasing for all the point rainfall stations and the highest decremental value was -0.515 for Pasyala. Three out of seven have an incremental trend for consecutive wet days (CWD) and the highest value was 0.344 for Pasyala. The highest decrease was -0.581 for Yatiyanthota. According to Table 1, the CWD has an incremental trend of 1.320 and while there is a decremental trend of 0.140 for CDD. It signifies that in future, the consecutive wet days would increase as a result of climate change, under changes of temperature and other anthropogenic factors.

\section{Extremes of Temperature}

To evaluate the extremes of temperature, the long-term $(1970$ - 2015) trend of the indices were identified by using two selected temperature stations, namely Colombo and Nuwara Eliya using average temperature in Kelani River basin. Table 4 shows the summary results, the trends of extreme indices of temperature. According to the results, trend of Summer Days of annual count when daily maximum temperature $>25^{\circ} \mathrm{C}$ (SU25) has an incremental value of 0.784 which indicates an increasing of summer days in Kelani River basin. Further, the Tropical Nights (TR20) have an increasing trend of 0.905 for the average temperature in Kelani River basin. The Warm Nights of percentage of days when temperature minimum $>90^{\text {th }}$ percentile (TN90p) shows an increasing trend of $0.767,1.028$ and 0.819 for average temperatures in Kelani basin, Colombo and NuwaraEliya, respectively. The trend of Warm Days or parentage of days when temperature maximum $>90^{\text {th }}$ percentile (TX90p) for average temperature of Kelani basin, Colombo and Nuwara-Eliya are $-0.076,0.168$ and -0.332 , respectively. The increasing trends of TX90p and TN90p are indicative of the changes in climate within the selected watershed (Relslnger \& Pachaurl, 2007, IPCC 2007).

\section{Climate Data Downscaling}

\section{Screening of Predictors}

The screening of predictors is central to all statistical downscaling (Huang et al., 2010). The selection of the first and most suitable large-scale variable is relatively easy, but the selection of subsequent variables become more subjective than the first. Therefore, more quantitative and qualitative methods of selection of suitable predictors of large-scale variables for each local-variable at each of the climate stations (Mahmood \& Babel, 2012) from the NCEP (National Centre for Environmental Predictions) predictors at an individual stations would be needed. The variance of the screening process in SDSM (Statistical Downscaling Model) describes the level of daily variations in the predictand determined by the predictor variables. To explain the strength of the relationship between the predictor and predictand, the correlation statistics and Partial Correlation value (P) were used. A higher $\mathrm{P}$ value reflects the fact that the predictor and predictand correlation could be significantly chance related while a lower $\mathrm{P}$ values indicate a better chance to represent the variables of predictand by predictors. 


\section{Calibration and Validation of SDSM}

Based on the available observed daily data, data from 1970-2000 was used for the calibration of the precipitation (PRCP), $\mathrm{T}_{\max }$ and $\mathrm{T}_{\min }$. In this study, SDSM was developed with NCEP predictors using monthly and seasonal sub-models. The conditional sub-model was used for Tmax and Tmin without any transformation and unconditional sub-model was used for precipitation with fourth root transformation. Optimization of the best fit is achieved following the ordinary least square method. To evaluate the performance of the SDSM, the explained variance (EV) and standard error (SE) were used (Huang et al., 2010).

The outputs of the SDSM were compared with the observed data by calculating the coefficient of determination $(\mathrm{R} 2)$, root mean square error (RMSE), mean $(\mu)$, standard deviation $(\sigma)$, relative error in mean $\left(\mathrm{RE}_{-} \mu\right)$ and relative error in standard deviation $\left(\mathrm{RE}_{-} \sigma\right)$ for precipitation, temperature maximum and temperature minimum for the periods of calibration and validation. The bias correction (Salzmann et al., 2007) method explained in Eqn. (1) and Eqn. (2) were used to obtain more realistic and unbiased data of future climate, as;

$\mathrm{T}_{\mathrm{deb}}=\mathrm{T}_{\mathrm{SCEN}}-\left(\mathrm{T}_{\mathrm{CONT}}-\mathrm{T}_{\mathrm{obs}}\right)$

$\mathrm{P}_{\mathrm{deb}}=\mathrm{P}_{\mathrm{SCEN}} \mathrm{x}\left(\mathrm{P}_{\mathrm{obs}} / \mathrm{P}_{\mathrm{CONT}}\right)$

Where $T_{\text {deb }}$ and $P_{\text {deb }}$ are the de-biased daily time series of temperature and precipitation respectively for validation and future periods. The SCEN represents the scenario data downscaled by SDSM for future periods (eg. 2006-2100), and CONT represents downscaled data by SDSM for the present period (1970-2000). The $\mathrm{P}_{\mathrm{SCEN}}$ and $\mathrm{T}_{\mathrm{SCEN}}$ are the daily time series of precipitation and temperature generated by the SDSM for future periods, respectively. $\mathrm{P}_{\mathrm{CONT}}$ and $\mathrm{T}_{\mathrm{CONT}}$ are the long-term mean monthly values for precipitation and temperature, respectively for the control period simulated by the SDSM. The $\mathrm{P}_{\mathrm{obs}}$ and $\mathrm{T}_{\mathrm{obs}}$ represents the longterm mean monthly observed values of precipitation and temperature respectively. Further, the frequency and intensity of precipitation are the two distinct main factors affecting the precipitation variability (Eisner et al., 2013) and the application of this method would be to correct the amount of precipitation not the frequency.

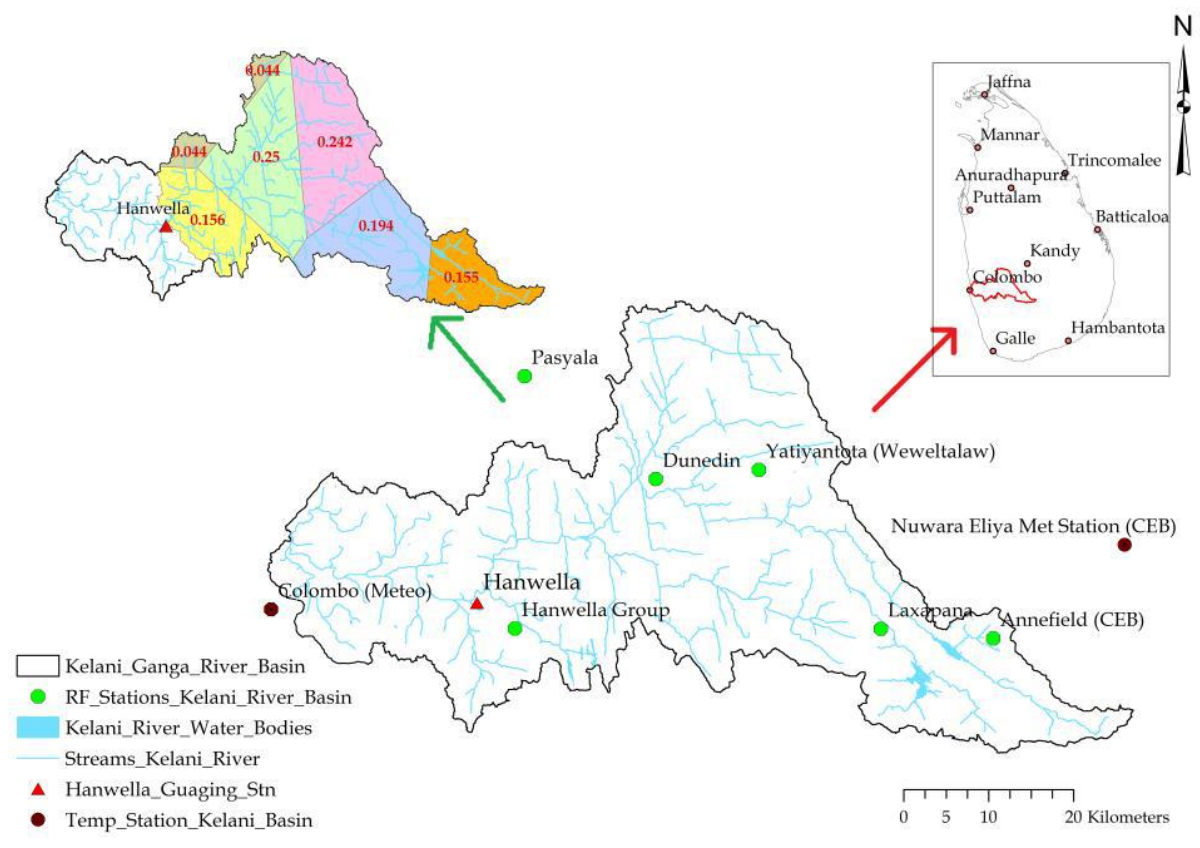

Figure 1 Study Area Map of Kelani River Basin with Rainfall and Stream Gauging Station Locations and Thiessen Polygans 
K.D.C.R. Dissanayaka \& R.L.H.L. Rajapakse / Climate Extremes And Precipitation Trends In.....

Table 1 Trends of Precipitation Extreme Indices in Kelani River Basin (1970-2015)

\begin{tabular}{lccccccc}
\hline Index & Colombo & Hanwella & Laxapana & Annfield & Pasyala & Dunedin & Yatiyanthota \\
\hline R10 & 0.022 & -0.185 & -0.519 & -0.158 & 0.017 & -0.067 & -0.492 \\
\hline R20 & 0.085 & 0.054 & -0.225 & -0.123 & -0.002 & -0.146 & -0.390 \\
\hline R95p & 1.424 & 0.183 & -6.548 & -3.048 & -0.385 & -3.485 & -10.145 \\
\hline R99p & 0.602 & -0.439 & -2.258 & -0.850 & -0.499 & -1.136 & -3.593 \\
\hline RX-1 day & 0.516 & 0.067 & 0.089 & -0.461 & 0.028 & -0.100 & -0.471 \\
\hline RX-5 day & 0.297 & -0.534 & -2.007 & -0.649 & -0.564 & -1.113 & -3.629 \\
\hline CDD & -0.146 & -0.258 & -0.192 & -0.217 & -0.515 & -0.117 & -0.236 \\
\hline CWD & -0.015 & -0.581 & -0.134 & -0.024 & 0.287 & 0.344 & 0.068 \\
\hline AVCPTOT & 4.095 & -4.850 & -20.333 & -7.514 & 3.623 & -5.136 & -24.559 \\
\hline
\end{tabular}

Table 2 Trends of Temperature Extreme Indices in Kelani River Basin (1970-2015)

\begin{tabular}{lccc}
\hline Index & Kelani River Basin & Colombo & Nuwara Eliya \\
\hline SU25 & 0.784 & 0.012 & -0.181 \\
\hline TR20 & 0.905 & 0.124 & 0.000 \\
\hline TXx & -0.006 & 0.008 & -0.012 \\
\hline TNx & -0.003 & 0.011 & -0.002 \\
\hline TXn & 0.019 & 0.015 & 0.015 \\
\hline TNn & 0.074 & 0.030 & 0.040 \\
\hline TN10p & -1.366 & -1.125 & -0.548 \\
\hline TX10p & -0.580 & -0.626 & -0.364 \\
\hline TN90p & 0.767 & 1.028 & 0.819 \\
\hline TX90p & -0.076 & 0.168 & -0.332 \\
\hline DTR & -0.018 & -0.019 & -0.017 \\
\hline ETR & -0.079 & -0.023 & -0.052 \\
\hline
\end{tabular}

\section{Calibration and Validation of Precipitation}

Precipitation was calibrated for the period 1970-2000 and validated for the period of 2001-2005. Figures 3 and 4 illustrate the graphical representation of calibration and validation of rainfall for Hanwella sub-watershed area. Further, Tables 4 and 5 depict details about the statistical analysis of modelling of precipitation.

Table 3 Summary Statistics of Calibration of Precipitation for the Period of 1970-2000 (Hanwella Subwatershed)

\begin{tabular}{lcccccc}
\hline Rainfall & $\mathrm{R}^{2}$ & $\mathrm{RMSE}(\mathrm{mm})$ & $\mu(\mathrm{mm})$ & $\sigma(\mathrm{mm})$ & $\mathrm{RE} \_\mu(\%)$ & $\mathrm{RE} \sigma \sigma(\%)$ \\
\hline Observed & & & 11.11 & 16.38 & & \\
\hline NCEP-M & 0.9954 & 18.95 & 11.14 & 11.80 & -0.22 & 27.92 \\
\hline NCEP-S & 0.8719 & 18.95 & 11.12 & 11.41 & -0.07 & 30.34 \\
\hline
\end{tabular}


Table 4 Summary Statistics of Validation of Precipitation for the Period of 2001-2005 (Hanwella Subwatershed)

\begin{tabular}{lcccccc}
\hline Rainfall & $\mathrm{R}^{2}$ & $\mathrm{RMSE}(\mathrm{mm})$ & $\mu(\mathrm{mm})$ & $\sigma(\mathrm{mm})$ & $\mathrm{RE} \_\mu(\%)$ & $\mathrm{RE} \sigma \sigma(\%)$ \\
\hline Observed & & & 9.34 & 10.98 & & \\
\hline NCEP-M & 0.9239 & 15.90 & 10.33 & 11.06 & -9.84 & -8.77 \\
\hline NCEP-S & 0.9250 & 16.32 & 10.20 & 11.46 & -8.49 & -32.39 \\
\hline
\end{tabular}
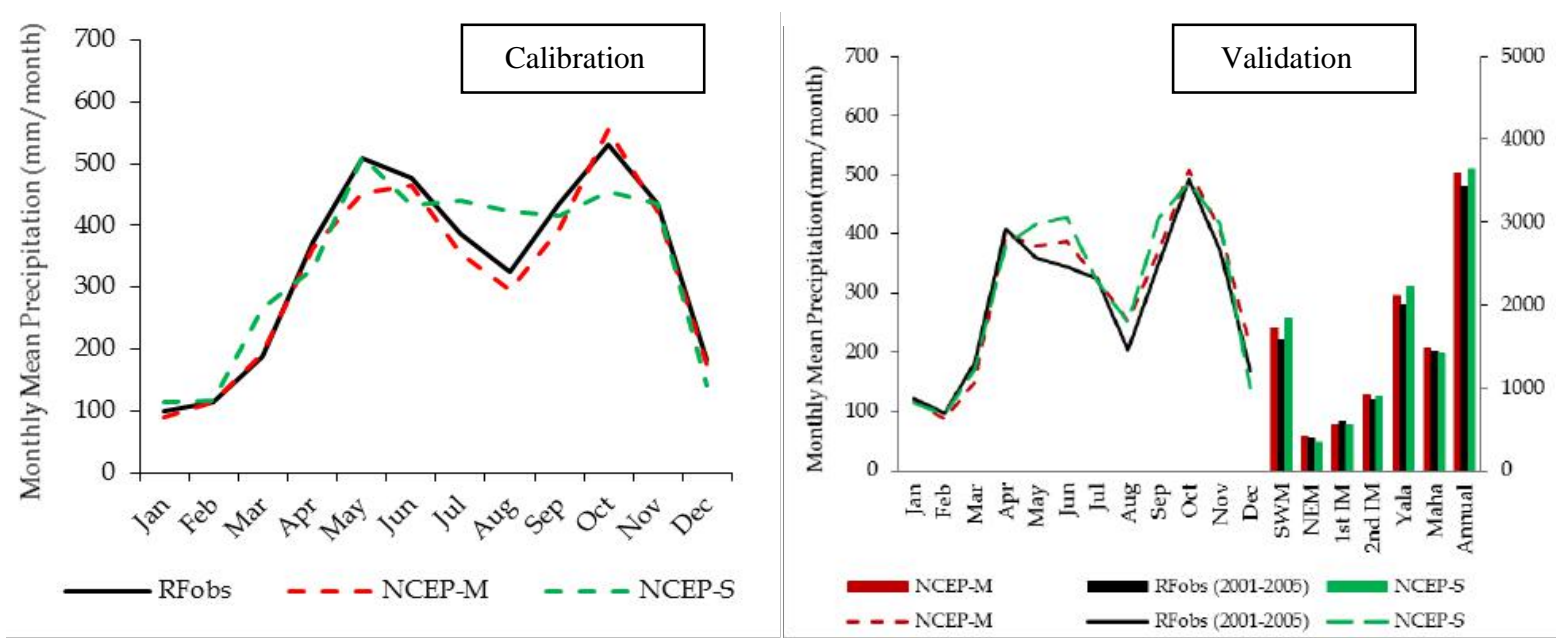

Figure 2 Calibration (1970 -2000) and Validation (2001-2005) of Precipitation for Hanwella Sub-watershed

*SWM - South West Monsoon (May - September), NEM - North East Monsoon (December - February), 1st IM - First inter monsoon (March - April), 2nd IM - Second inter monsoon (October - November), Yala - April to September, Maha - October to March

According to Figure 2, the modelled rainfall for SDSM-S is over-estimated for the month of March, July and August by $41.47 \%, 13.70 \% \& 29.85 \%$, respectively and under-estimated for the months of October and December by $14.42 \% \& 23.24 \%$, respectively. According to Figure 2, the modelled rainfall for SDSM-S is overestimated in the months of May, June and August by $16.1 \%, 24.0 \%$ \& 22.9\%, respectively. The modelled rainfall for SDSM_M for both calibration and validation do not give any significant changes like in SDSM-S.

\section{Calibration and Validation of Temperature}

Temperature change was observed covering the entire Kelani River basin following Thiessen polygon method. Temperature was calibrated for the period of 1970-2000 similar to precipitation and validated for the same

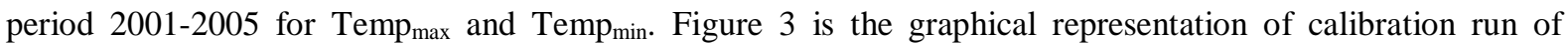

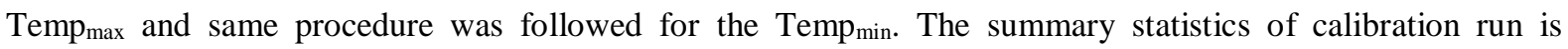
tabulated in Table 5 and for validation in Table 6, respectively, according to the monthly and seasonal submodels.

According to Table 5, the maximum relative error of mean is $0.004{ }^{\circ} \mathrm{C}$ with a standard deviation of $-0.09^{\circ} \mathrm{C}$.

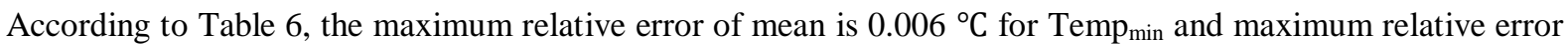
of standard deviation is $-0.15^{\circ} \mathrm{C}$ for Temp $\max$. 
K.D.C.R. Dissanayaka \& R.L.H.L. Rajapakse/Climate Extremes And Precipitation Trends In.....

Table 5 Summary Statistics of Calibration of Temperature for the Period of 1970-2000

\begin{tabular}{|c|c|c|c|c|c|c|c|}
\hline \multicolumn{2}{|c|}{ Temperature } & $\mathrm{R}^{2}$ & $\operatorname{RMSE}\left({ }^{\circ} \mathrm{C}\right)$ & $\mu\left({ }^{\circ} \mathrm{C}\right)$ & $\sigma\left({ }^{\circ} \mathrm{C}\right)$ & $\mathrm{RE} \_\mu\left({ }^{\circ} \mathrm{C}\right)$ & RE_ $\sigma\left({ }^{\circ} \mathrm{C}\right)$ \\
\hline \multirow{3}{*}{$\stackrel{\text { ઁ }}{\Sigma}$} & Obs. & & & 25.83 & 1.55 & & \\
\hline & NCEP-M & 0.9991 & 1.741 & 25.83 & 1.62 & 0.004 & -0.04 \\
\hline & NCEP-S & 0.9988 & 1.765 & 25.83 & 1.64 & 0.000 & -0.05 \\
\hline \multirow{3}{*}{$\stackrel{\equiv}{\Sigma}$} & Obs. & & & 18.49 & 1.51 & & \\
\hline & NCEP-M & 0.9993 & 1.864 & 18.49 & 1.60 & 0.002 & -0.06 \\
\hline & NCEP-S & 0.9958 & 1.881 & 18.5 & 1.65 & 0.003 & -0.09 \\
\hline
\end{tabular}

Table 6 Summary Statistics of Validation of Temperature for the Period of 2001-2005

\begin{tabular}{|c|c|c|c|c|c|c|c|}
\hline \multicolumn{2}{|c|}{ Temperature } & $\mathrm{R}^{2}$ & RMSE $\left({ }^{\circ} \mathrm{C}\right)$ & $\mu\left({ }^{\circ} \mathrm{C}\right)$ & $\sigma\left({ }^{\circ} \mathrm{C}\right)$ & $\mathrm{RE} \_\mu\left({ }^{\circ} \mathrm{C}\right)$ & RE_ $\sigma\left({ }^{\circ} \mathrm{C}\right)$ \\
\hline \multirow{3}{*}{$\sum_{\Sigma}^{\star \pi}$} & Obs. & & & 25.97 & 1.41 & & \\
\hline & NCEP-M & 0.9719 & 1.713 & 25.89 & 1.62 & 0.003 & -0.15 \\
\hline & NCEP-S & 0.9405 & 1.677 & 25.91 & 1.61 & 0.002 & -0.14 \\
\hline \multirow{3}{*}{$\stackrel{\Xi}{\Sigma}$} & Obs. & & & 19.14 & 1.54 & & \\
\hline & NCEP-M & 0.9610 & 1.586 & 19.09 & 1.68 & 0.003 & -0.09 \\
\hline & NCEP-S & 0.9784 & 1.600 & 19.04 & 1.70 & 0.006 & -0.10 \\
\hline
\end{tabular}
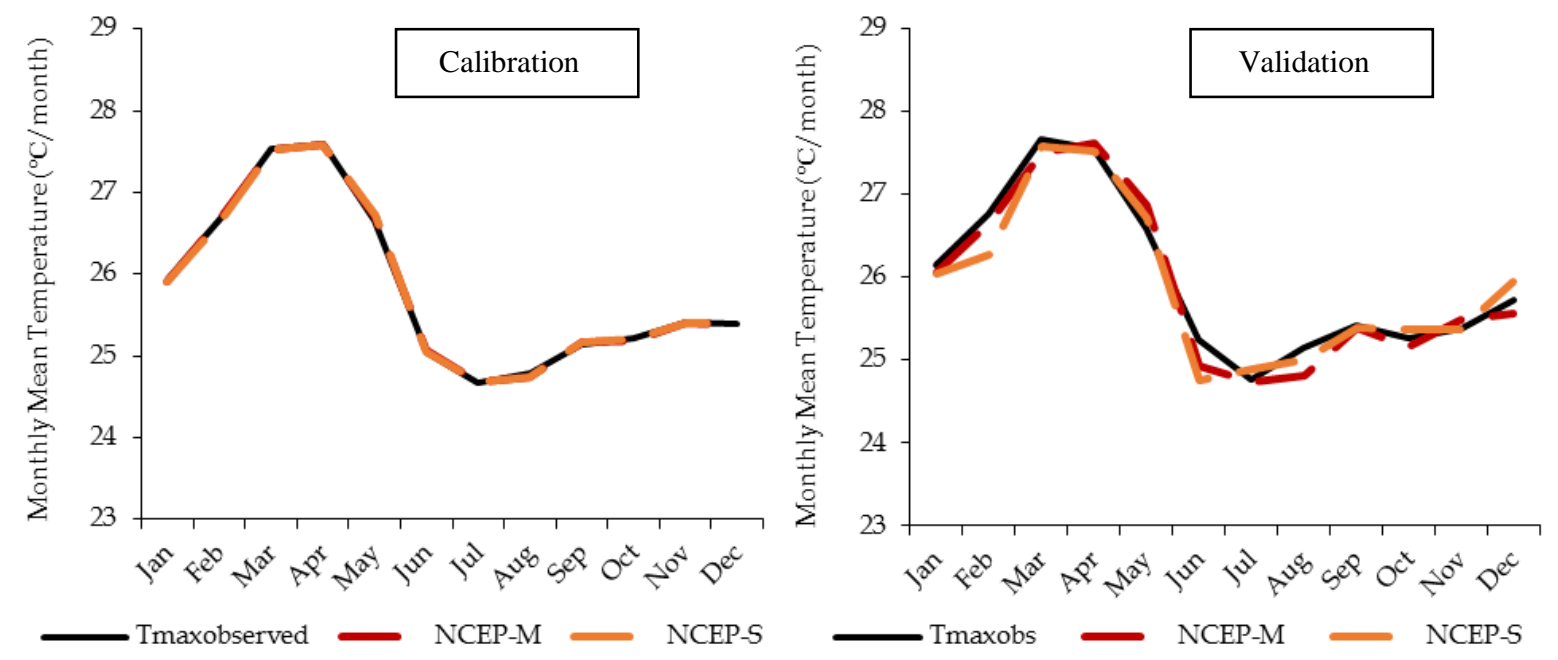

Figure 3 Calibration (1970-2000) and Validation (2001-2005) of Temperature Maximum in Kelani River Basin

According to Figure 3, the SDSM-S modelled result has deviated within the period of January to March and June to August with the observed and for SDSM-M model result has deviated between June to August. Maximum RMSE error was $1.713{ }^{\circ} \mathrm{C}$ for $\mathrm{Temp}_{\max }$ for SDSM-M model. Figure 3 show the graphical representation of the modelled output for the validation run of Temp max $_{\text {ax }}$ and Table 6 presents the summary statistics of the modelled validation run result for Temp $\mathrm{max}_{\max }$ and Temp $\mathrm{Tin}_{\min }$ respectively for the period of 20012005.

\section{Future Change of Catchment Rainfall}

Hanwella sub-watershed is selected for the present study to identify climate change impact on catchment rainfall. Table 7 represents the future changes in seasonal and annual mean precipitation in the Hanwella subwatershed for the periods of 2020s (2010-2039), 2050s (2040-2069) and 2080s (2070-2099) with respect to the selected baseline period of 1970-2000 under RCP2.6, RCP4.5 and RCP8.5 scenarios obtained from the two submodels of SDSM-M and SDSM-S. These two sub-models give the mean annual increments with respect to the baseline period in the 2020s, 2050s and 2080s, respectively. The results were tabulated in the Table 7 as the 
changes of catchment rainfall. The changes in the precipitation predicted by two sub-models were different from each other with respect to the magnitude. Because of that, modelling only Hanwella sub-watershed was considered. Variation of the future precipitation in the Hanwella watershed and the Kelani River basin as identify by monthly sub-model are illustrated by the Figure A.1 and A.2 in the Appendix.

\section{Future Change of Temperature}

The temperature change was calculated for the Kelani River basin with respect to the observed data from Colombo and Nuwara-Eliya temperature gauging stations. Table 8 and Table 9 depict the results of the future changes of the Tmax and Tmin for catchment average temperature as increments or decrements to the average with respect to the SDSM-M and SDSM-S sub-models for the future periods of 2020s (2010-2039), 2050s (2040-2069) and 2080s (2070-2099) under RCP2.6, RCP4.5 and RCP8.5 scenarios. These increments or decrements in future temperature were estimated with respect to the baseline period of 1970-2000. According to Table 8, the maximum increase of $\mathrm{T}_{\max }$ was found to $1.64^{\circ} \mathrm{C}$ for $2020 \mathrm{~s}$ period by SDSM-S for RCP2.6 scenario, and maximum decrement of $\mathrm{T}_{\min }$ was found to be $-0.97^{\circ} \mathrm{C}$ for 2020 s period by SDSM-S. Similarly, results obtained with SDSM-M for increase in $\mathrm{T}_{\max }$ were $1.09^{\circ} \mathrm{C}$ for $2050 \mathrm{~s}$ from RCP8.5 and $0.97^{\circ} \mathrm{C}$ for increase in $\mathrm{T}_{\min }$ for 2020s from RCP2.6. Variation of the future temperature in the Kelani River basin as identified by monthly sub-model is illustrated by the Figure A.3 in the Appendix by.

Table 7 Future Changes of Catchment Rainfall (\%) of Hanwella Sub-watershed under RCP2.6, RCP4.5 \& RCP8.5 Scenarios

\begin{tabular}{|c|c|c|c|c|c|c|c|}
\hline \multirow{2}{*}{\multicolumn{2}{|c|}{ Season }} & \multicolumn{3}{|c|}{ SDSM-M (\%) } & \multicolumn{3}{|c|}{ SDSM-S (\%) } \\
\hline & & $2020 \mathrm{~s}$ & $2050 \mathrm{~s}$ & $2080 \mathrm{~s}$ & $2020 \mathrm{~s}$ & $2050 \mathrm{~s}$ & $2080 s$ \\
\hline \multirow{7}{*}{$\begin{array}{l}0 \\
i \\
\tilde{\nu} \\
\simeq\end{array}$} & SWM & 14.33 & 18.40 & 16.75 & 0.60 & 1.96 & 2.37 \\
\hline & NEM & -0.26 & -6.40 & 1.21 & 12.21 & 9.72 & 8.56 \\
\hline & $1^{\text {st }} \mathrm{IM}$ & -0.02 & -1.02 & -2.50 & 4.47 & -2.86 & 6.02 \\
\hline & $2^{\text {nd }} I M$ & 2.73 & -1.63 & -1.87 & 13.11 & 15.38 & 16.87 \\
\hline & Yala & 12.35 & 16.18 & 15.13 & 3.65 & 3.67 & 4.13 \\
\hline & Maha & 0.79 & -3.85 & 2.09 & 7.85 & 7.81 & 7.67 \\
\hline & Annual & 7.93 & 8.51 & 9.24 & 5.25 & 5.26 & 6.32 \\
\hline \multirow{7}{*}{ 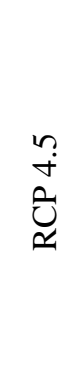 } & SWM & 15.65 & 13.28 & 14.58 & 0.88 & 3.76 & 2.89 \\
\hline & NEM & -5.94 & -3.29 & -3.05 & 14.73 & 17.54 & 16.81 \\
\hline & $1^{\mathrm{st}} \mathrm{IM}$ & -2.13 & -1.58 & -2.97 & 1.42 & 5.29 & 6.01 \\
\hline & $2^{\text {nd }} I M$ & 0.48 & 5.00 & 4.38 & 13.37 & 16.68 & 13.15 \\
\hline & Yala & 13.72 & 11.88 & 14.16 & 3.59 & 7.37 & 4.87 \\
\hline & Maha & -2.61 & 0.76 & 1.30 & 8.02 & 10.06 & 9.75 \\
\hline & Annual & 7.47 & 7.62 & 6.89 & 5.29 & 8.40 & 9.12 \\
\hline \multirow{7}{*}{$\begin{array}{l}n \\
\infty \\
\tilde{\nu} \\
\approx\end{array}$} & SWM & 13.62 & 13.54 & 12.33 & 2.44 & 5.95 & 4.01 \\
\hline & NEM & -0.23 & -5.35 & -6.01 & 15.31 & 13.42 & 16.75 \\
\hline & $1^{\text {st }} \mathrm{IM}$ & -1.59 & 0.92 & 1.05 & -0.28 & 3.20 & 4.11 \\
\hline & $2^{\text {nd }} I M$ & 1.48 & 2.21 & 1.93 & 14.36 & 17.28 & 17.01 \\
\hline & Yala & 12.17 & 11.91 & 11.87 & 4.53 & 8.13 & 7.56 \\
\hline & Maha & -0.64 & -0.29 & 1.00 & 8.80 & 10.40 & 9.59 \\
\hline & Annual & 7.26 & 7.24 & 8.05 & 6.16 & 9.00 & 10.34 \\
\hline
\end{tabular}


K.D.C.R. Dissanayaka \& R.L.H.L. Rajapakse/Climate Extremes And Precipitation Trends In.....

Table 8 Future Change of Average Maximum Temperature in Kelani River Basin

\begin{tabular}{|c|c|c|c|c|c|}
\hline \multirow{3}{*}{\multicolumn{2}{|c|}{$\begin{array}{l}\text { Kelani River } \\
\text { Basin Tmax }\end{array}$}} & \multirow{2}{*}{\multicolumn{2}{|c|}{$\frac{\text { Observed Maximum }\left({ }^{\circ} \mathrm{C}\right)}{31.00}$}} & \multirow{2}{*}{\multicolumn{2}{|c|}{$\begin{array}{c}\text { Observed Minimum }\left({ }^{\circ} \mathrm{C}\right) \\
19.60\end{array}$}} \\
\hline & & & & & \\
\hline & & SDSM-M & SDSM-S & SDSM-M & SDSM-S \\
\hline \multirow{3}{*}{ ర్ } & RCP2.6 & 0.99 & 1.64 & 0.97 & 0.74 \\
\hline & RCP4.5 & 0.56 & 1.03 & 0.84 & -0.97 \\
\hline & RCP8.5 & 0.77 & 0.86 & 0.79 & 0.11 \\
\hline \multirow{3}{*}{ 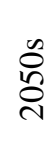 } & RCP2.6 & 0.87 & 0.83 & 0.78 & 0.24 \\
\hline & RCP4.5 & 0.52 & 0.84 & 0.87 & 0.07 \\
\hline & RCP8.5 & 1.09 & 1.13 & 0.64 & 0.03 \\
\hline \multirow{3}{*}{$\stackrel{\infty}{\infty}$} & $\mathrm{RCP} 2.6$ & 0.55 & 0.88 & 0.57 & 0.52 \\
\hline & RCP4.5 & 0.25 & 1.12 & 0.76 & 0.04 \\
\hline & RCP8.5 & 1.03 & 1.36 & 0.88 & 0.91 \\
\hline
\end{tabular}

Table 10 and Table 11 present the modelled maximum and minimum temperatures at Colombo and NuwaraEliya stations for future with respect to the baseline period of 1970-2000 for both sub-models.

Table 9 Future Change of Average Minimum Temperature in Kelani River Basin

\begin{tabular}{|c|c|c|c|c|c|}
\hline \multirow{3}{*}{\multicolumn{2}{|c|}{$\begin{array}{l}\text { Kelani River } \\
\text { Basin Tmin }\end{array}$}} & \multirow{2}{*}{\multicolumn{2}{|c|}{$\frac{\text { Observed Maximum }\left({ }^{\circ} \mathrm{C}\right)}{22.77}$}} & \multirow{2}{*}{\multicolumn{2}{|c|}{$\frac{\text { Observed Minimum }\left({ }^{\circ} \mathrm{C}\right)}{10.94}$}} \\
\hline & & & & & \\
\hline & & SDSM-M & SDSM-S & SDSM-M & SDSM-S \\
\hline \multirow{3}{*}{ ঠి } & RCP2.6 & 1.75 & 2.81 & 0.02 & 0.09 \\
\hline & RCP4.5 & 1.29 & 2.30 & -0.35 & -0.19 \\
\hline & RCP8.5 & 0.86 & 1.55 & -0.74 & 0.17 \\
\hline \multirow{3}{*}{ ஜ̊ } & RCP2.6 & 1.37 & 1.84 & 0.10 & -0.11 \\
\hline & RCP4.5 & 1.32 & 2.38 & -1.85 & -1.00 \\
\hline & RCP8.5 & 1.58 & 1.43 & -0.71 & -0.37 \\
\hline \multirow{3}{*}{$\overbrace{\substack{\infty \\
\infty}}^{\infty}$} & $\mathrm{RCP} 2.6$ & 1.41 & 1.89 & -0.65 & -0.93 \\
\hline & RCP4.5 & 1.32 & 1.96 & 0.11 & -0.79 \\
\hline & RCP8.5 & 0.71 & 2.55 & 0.34 & -1.22 \\
\hline
\end{tabular}

The maximum increase in temperature $\mathrm{T}_{\max }$ for Colombo was $2.18^{\circ} \mathrm{C}$ from SDSM-M in 2080s for RCP8.5, and for Nuwara-Eliya was $3.29^{\circ} \mathrm{C}$ from SDSM-M in 2020s for RCP2.6 scenarios respectively. 
Proceedings of the $2^{\text {nd }}$ International Conference on Climate Change, Vol. 2, Issue 2, 2018, pp. 01-17

Table 10 Future Change of Temperature Maximum at Point Temperature Stations in Colombo \& Nuwara-Eliya

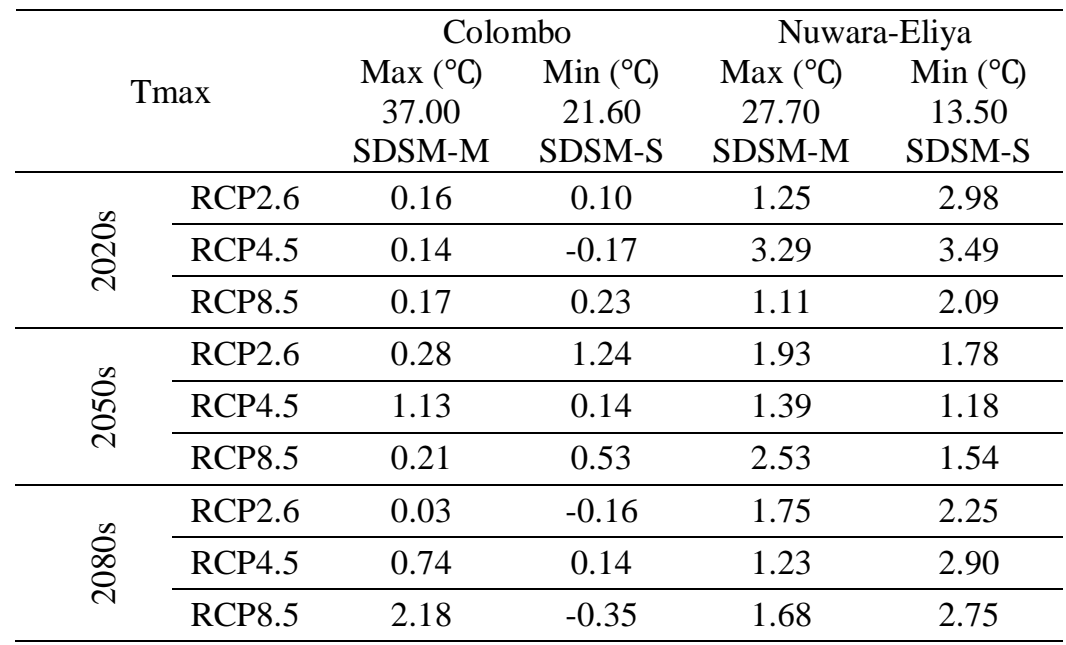

Table 11 Future Change of Temperature Minimum at Point Temperature Stations in Colombo \& Nuwara-Eliya

\begin{tabular}{|c|c|c|c|c|c|}
\hline & & \multicolumn{2}{|c|}{ Colombo } & \multicolumn{2}{|c|}{ Nuwara-Eliya } \\
\hline \multicolumn{2}{|c|}{ Tmin } & $\operatorname{Max}\left({ }^{\circ} \mathrm{C}\right)$ & $\operatorname{Min}\left({ }^{\circ} \mathrm{C}\right)$ & $\operatorname{Max}\left({ }^{\circ} \mathrm{C}\right)$ & $\operatorname{Min}\left({ }^{\circ} \mathrm{C}\right)$ \\
\hline & & & & & SDN1VI- \\
\hline \multirow{3}{*}{ 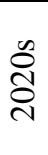 } & RCP2.6 & 2.12 & 2.38 & 3.61 & 4.51 \\
\hline & $\mathrm{RCP} 4.5$ & 2.14 & 1.86 & 4.88 & 4.42 \\
\hline & RCP8.5 & 2.18 & 2.27 & 3.52 & 4.47 \\
\hline \multirow{3}{*}{ 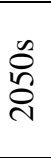 } & RCP2.6 & 1.93 & 2.26 & 4.58 & 3.89 \\
\hline & RCP4.5 & 3.08 & 1.75 & 3.54 & 3.41 \\
\hline & RCP8.5 & 2.39 & 3.25 & 4.01 & 3.76 \\
\hline \multirow{3}{*}{ 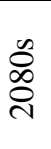 } & RCP2.6 & 1.86 & 1.74 & 5.91 & 3.60 \\
\hline & RCP4.5 & 1.97 & 1.25 & 3.67 & 4.29 \\
\hline & RCP8.5 & 2.18 & 2.16 & 3.42 & 5.95 \\
\hline
\end{tabular}

Further, the maximum increase of temperature $\mathrm{T}_{\min }$ for Colombo was $3.25^{\circ} \mathrm{C}$ from SDSM-S in 2050 s for RCP8.5, and for Nuwara-Eliya was $5.95^{\circ} \mathrm{C}$ from SDSM-M in 2080s period from RCP8.5 as well. According to the results, the increase in minimum temperature $T_{\min }$ is greater than the increase in maximum temperature $T_{\max }$.

Future Variation of Streamflow

The Hanwella sub-watershed was selected to evaluate the future change in streamflow in Kelani River basin. It was decided partly based on the availability of the existing calibrated HEC-HMS model for Hanwella subwatershed (De Silva et al., 2014). This model was developed to calculate the streamflow based on event based and continuous rainfall data series. Due to the non-stationarity of the precipitation, there would be a significant change in the results of the modelled streamflow with respect to the observed flow. Hence, by changing the baseflow parameters of the model, a sensitivity check was performed to verify the computation capacity of the selected model for streamflow with respect to the selected objective functions of Nash-Suctliffe (NASH) and Mean Ratio of Absolute Error (MRAE). This non-stationarity phenomenon of the precipitation is a result of climate change and change of runoff (Patabandige, Kazama \& Komori, 2016). For baseline period (1985-2010) and the predicted periods (2020s, 2050s and 2080s), the streamflow means matched the RCP scenarios for both monthly and seasonal sub-models of SDSM-M and SDSM-S. The overall performance of the application of calibrated model giving values of 0.749 for NASH, 0.502 for MRAE and $-3.15 \%$ for Mass Balance Error percentage. The future change of streamflow of Hanwella sub-watershed altogether decreased with respect to 
the climate forcing criteria (Table 12), which is well convincing that there exists a change of water availability in seasonal and annual basis to the mean of observed streamflow of Kelani river basin.

Table 12 Percentage of Future Change of Streamflow in Hanwella Sub-watershed for RCP2.6, RCP4.5 and RCP8.5 Scenarios

\begin{tabular}{|c|c|c|c|c|c|c|c|}
\hline \multirow{2}{*}{\multicolumn{2}{|c|}{ Season }} & \multicolumn{2}{|c|}{ RCP2.6 (\%) } & \multicolumn{2}{|c|}{ RCP4.5 (\%) } & \multicolumn{2}{|c|}{ RCP8.5 (\%) } \\
\hline & & SDSM_M & SDSM_S & SDSM_M & SDSM_S & SDSM_M & SDSM_S \\
\hline \multirow{7}{*}{ ర్ర } & SWM & 0.67 & 5.29 & -0.31 & -3.17 & 0.80 & -1.28 \\
\hline & NEM & 1.31 & 2.69 & -7.34 & 7.24 & 0.73 & 4.02 \\
\hline & $1^{\mathrm{st}} \mathrm{IM}$ & -1.79 & 5.91 & -0.50 & 0.10 & 0.19 & 0.26 \\
\hline & $2^{\text {nd }} I M$ & -2.87 & -7.32 & -11.0 & -7.17 & -5.83 & -5.36 \\
\hline & Yala & -0.45 & -4.17 & -0.85 & -3.01 & -.021 & -1.34 \\
\hline & Maha & -0.51 & -3.01 & -8.35 & -2.41 & -3.14 & -2.04 \\
\hline & Annual & -0.47 & -3.71 & -3.85 & -2.77 & -1.34 & -1.62 \\
\hline \multirow{7}{*}{$\stackrel{n}{8}$} & SWM & 3.27 & -1.91 & -3.27 & -1.90 & 1.05 & 1.82 \\
\hline & NEM & -6.93 & 3.95 & -3.97 & 12.37 & -0.93 & 8.18 \\
\hline & $1^{\text {st }} \mathrm{IM}$ & 0.88 & -1.26 & -1.22 & 4.68 & 3.23 & 2.99 \\
\hline & $2^{\text {nd }} \mathrm{IM}$ & -14.1 & -4.08 & -2.70 & 0.59 & -7.16 & -0.61 \\
\hline & Yala & 2.57 & -2.04 & -340 & -0.51 & 0.72 & 1.75 \\
\hline & Maha & -10.3 & -1.43 & -2.31 & 3.22 & -3.70 & 2.31 \\
\hline & Annual & 2.59 & -1.80 & -2.96 & 0.98 & -1.05 & 1.98 \\
\hline \multirow{7}{*}{$\stackrel{\infty}{\infty}$} & SWM & 1.01 & 1.09 & 0.75 & -2.33 & -4.05 & 6.43 \\
\hline & NEM & -5.41 & 4.60 & 5.02 & 3.31 & 0.58 & 9.62 \\
\hline & $1^{\text {st }} \mathrm{IM}$ & 0.19 & -0.98 & -1.06 & 2.20 & 7.30 & 3.67 \\
\hline & $2^{\text {nd }} I M$ & -7.95 & 1.91 & 6.18 & 3.65 & -9.55 & -3.94 \\
\hline & Yala & 0.61 & 0.49 & 1.29 & -1.10 & -2.66 & 5.23 \\
\hline & Maha & -6.13 & 2.83 & 5.98 & 2.40 & -5.26 & 1.49 \\
\hline & Annual & -2.09 & 1.43 & 1.62 & 0.33 & -3.70 & 3.74 \\
\hline
\end{tabular}

Figure 8 in Appendix illustrating the goodness of fit for streamflow modelling and Figure 9 shows the goodness of fit of the modelled and observed streamflow at Hanwella gauging station.

\section{Discussion}

Scientists are unanimous that the impending changes in climate patterns would be global and regional in scope and scale. Several studies have predicted that developing countries are likely to face greater hardships and within them also the poorer communities are more vulnerable for impacts of climate change (Stern, 2007). Sri Lanka is a developing/middle income country with a significant population having lower income range. Further, as a topical island located in the South Asia region, it frequently experiences disaster prone weather extremes. By the way, in combination of these factors (i.e.: being a tropical island of significant low income population and located in a disaster prone region closer to bay of Bengal) makes Sri Lanka a highly vulnerable country to climate change in terms of physical as well as socio economic impacts.

In this present study, according to the extreme analyses, there are 10 indices used for precipitation and 12 indices for temperature for the observed data for the period of 1970-2015. Comparison of the 1970-2015 trends with the changes over the period of 1961-2000 and 1901-2000 for the region (Klein Tank et al., 2006) illustrates that linear trends need to be interpreted with care, as they may not be a good representation of the actual change in a variable selected. Where the observed trends may indeed be a part of the long term trends, this would be a 
reasonable estimate for TN10 and TN90. Otherwise they may also be a part of slow fluctuations of the climate, which is the reason for TX10 and TX90. Further, a detailed analyses are necessary to provide the reason for the different values obtained with respect to the long-term trends of the minimum and maximum temperature extremes. In contrast to the extremes of temperature, there was no robust signal of changes in precipitation extremes were observed either for the period of 1970-2015, when checked for outliers. Therefore, relative to the changes in the average annual total amounts of river basin, there is a slight indication of disproportionately large changes in the extremes. Although the precipitation indices are calculated on an annual basis, they will be dominated by the precipitation in the wet zone, particularly with respect to the monsoonal seasons. Hence, from an impact point of view, indices used and that represent the start and end of the monsoonal season may be more appropriate in the area of study. Further, the changes in climate at the river basin scale are largely the result of variability in large-scale atmospheric circulation patterns. This means that the observed trends can be partly understood by studying the correlation with accompanying changes in large-scale atmospheric circulation. Moreover, Archer et al., (2004) identified a significant positive correlation between precipitation in the Indus Basin and the North Atlantic Oscillation Index. Hence to know up to what extent the trends of the present study are related with atmospheric circulation changes need to be addressed in future studies. Meanwhile, in any time series, changes in routine observing practices may have introduced inhomogeneities of non-climatic origin that may severely affect the extremes of precipitation and temperature within the study area. Even though if each time series has been carefully scrutinized, the results for individual stations may be affected by inhomogeneities in the underlying series that were not detected. Therefore robust conclusions are only drawn from tendencies over large areas and regional average trends.

To analyze the effect of future change of climate in the watershed scale, the well-known decision support tool, namely the Statistical Downscaling Model (SDSM), was applied with the CanESM2 GCM to analyze the spatial and temporal future variations in temperature maximum, temperature minimum and precipitation in the Kelani River basin and Hanwella Sub-watershed under RCP scenarios. The downscaling of these three variables are very important in order to study the impacts related to the climate change in the streamflow variation in the Kelani basin in future. The screening of predictors introduced by (Mahmood \& Babel, 2012) well represented the climate modelling in Kelani River basin and it substantiates the applicability of the climate change studies in to different watersheds. Further, the SDSM showed good capability in modelling Tmax and Tmin in daily, monthly, seasonally and annually time series, during the calibration and validation processes with respect to the NCEP/NCAR data (Herath et al., 2012). The average annual $\mathrm{T}_{\max }$ and $\mathrm{T}_{\min }$ were projected to increase in the Kelani River basin under RCP2.6, RCP4.5 and RCP8.5 scenarios in all three consecutive future periods of 2020s, 2050s and 2080s. The maximum increases were shown in Tmin than Tmax in the Kelani basin. Further, the point temperature of Tmax and Tmin would be increased in future under the three RCP scenarios in respective stations of Colombo and Nuwara-Eliya used for the present study. The average annual precipitation in Hanwella sub-watershed of the Kelani River basin was predicted to increase by $5.24 \%$ to $10.34 \%$ under three scenarios with more frequent occurrence of extreme events. This was the phenomena of changing the average annual precipitation with respect to the baseline period. The South-West monsoon and the North-East monsoon were the most affected seasons in the Hanwella sub-watershed under three scenarios and all three future periods. As for the whole Kelani River basin, Maha (April to August) and Yala (September to March) seasons were projected to receive more precipitation, and $1^{\text {st }} \mathrm{IM}$ and $2^{\text {nd }}$ IM receive lesser amounts of precipitation with respect to the SDSM-M than SDSM-S in the future as compared to the baseline period of 1970-2000. The streamflow in the Kelani River basin with respect to the Hanwella sub-watershed will be increased in between the months of April to June and decreased in between August to October than that of the baseline period of streamflow simulation of 1985-2010 under the three scenarios in future periods. The selected HEC-HMS model for streamflow simulation performed well up to $75 \%$ of streamflow modelling. The overall changes of the Tmax, Tmin and PRCP under three scenarios of RCP represented an increasing trend (De Silva et al., 2014) than baseline period while the streamflow indicated a decreasing trend similar to that observed for Hanwella subwatershed in Kelani River basin. Moreover, the predicted change of the climatology would be a result of other anthropogenic factors as well. 


\section{Conclusions}

With the standardized descriptive indices, a better understanding of observed changes in the temperature and precipitation extremes is gained for Kelani River Basin. In addition to the trends over 1961-2000, longer time series for a limited number of stations are used to place the 45-year changes in extremes analysis in a longerterm period of 1970-2015. For Kelani River Basin, SU25, TR20 and TN90 have significantly increased for the period of 1970-2015. No consistent pattern of the changes in precipitation extremes could be detected for the majority of precipitation indices. Most of the indices are showing decreasing trends for total precipitation except two stations from the selected individual stations of the study for the period of 1970-2015. The use of RCM for this type of study is best fitted than with the use of GCMs to evaluate the future predictions. For present study, the statistical downscaling technique was used to calibrate and validate the GCM model output and as well as to evaluate the future change of the climate to base period. The hydrologic model used for streamflow forecasting is a model previously calibrated for the basin and it is suggested to use a different hydrologic model like ArcSWAT for future evaluation of streamflow changes with respect to the climate change for better insight of the impacts. The use of different GCMs and RCMs can be implemented to check the reliability of predictions, while application for different watersheds will help establishing the uncertainty incorporated with different models in climate change studies.

\section{Acknowledgment}

This study is the outcome of the first author's postgraduate research, conducted at University of Moratuwa. The authors wish to acknowledge and offer gratitude to Meteorological Department of Sri Lanka, Irrigation Department of Sri Lanka, Canadian Centre for Climate Modelling and Analysis, CORDEX South Asia and University of Moratuwa for providing important and valuable data for the research. Heartfelt gratitude is also extended to the UNESCO-Madanjeet Singh Centre for South Asia Water Management (UMCSAWM) and South Asian Foundation (SAF-India) for providing financial support to the first author's research and special thank for Prof. R. L. Wilby \& Dr. Saheb ul-Hasson, who has provided guidance to this case study.

\section{References}

Archer, D. R., and Fowler, H.J., 2004. Spatial and temporal variations in precipitation in the upper Indus basin, global teleconnections and hydrological implications, HESS, 8, 47-61.

De Silva, M. M. G. T., Weerakoon, S. B., and Herath, S., 2014. Modelling of event and continuous flow hydrographs with HEC-HMS: case study in the Kelani River basin, Sri Lanka. Journal of Hydrologic Engineering, 800-806

Eisner, S., Schewe, J., Gerten, D., Heinke, J., Haddeland, I., Anrell, N. W., and Kabat, P., 2013. Multimodal assessment of water scarcity under climate change. Sustainability Science, 111(No. 09), 3245-3250.

Fowler, H. J., Kilsby, C. G., and Stunell, J., 2007. Modelling the impacts of projected future climate change on water resources in North-west England. Hydrology \& Earth System Science, 11(3), 1115-1126.

Frich, P., Alexander, L. V., Della-Marta, P., Gleason, B., Haylock, M., Klein Tank, A. M. G., and Peterson, T., 2002. Observed coherent changes in climatic extremes during the second half of the twentieth century. Climate Research, 19, 193-212.

Gebremeskel, S., and Li, Y., 2005. Analysing the effect of climate changes on streamflow using statistically downscaled GCM scenarios. International Journal of River Basin Management, 271-280.

Hasson, S., Lucarini, V., and Pascale, S. 2013, Hydrological Cycle over South and Southeast Asian river basin as simulated by PCMDI/CMIP3 experiments. Earth System Dynamics.

Herath, S., Weerakoon, S. B., Kawasaki, J., Koontanakulvong, S., Thuc, T., Tuan, L. A., and Tabios, G. Q., 2012. Comparative studies on development strategies considering impacts of adaptation to climate change. Report on Climate Change Adaptation Research Funded by Mitsui Corporation. 
Huang, J., Zhang, J., Zhang, Z., Xu, C. Y., Wang, B., and Yao, J., 2010. Estimation of future precipitation change in the Yangtze River basin by using statistical downscaling method. Springer - Stochastic Environmental Research and Risk Assessment, 25, 781-792.

IPCC, 2007: Climate Change 2007: The Physical Science Basis. Contribution of Working Group I to the Fourth Assessment Report of the Intergovernmental Panel on Climate Change. [Solomon, S., Qin, D., Manning, M., Chen, Z., Marquis, M., Averyt, K. B., Tignor M., and Miller H. L., (eds.)]. Cambridge University Press, Cambridge, United Kingdom and New York, NY, USA, 996 pp.

IPCC, 2013b: Climate Change 2013: The Physical Science Basis. Contribution of Working Group I to the Fifth Assessment Report of the Intergovernmental Panel on Climate Change [Stocker, T. F., Qin, D., Plattner, G. K., Tignor, M., Allen, S. K., Boschung, J., Nauels, A., Xia, Y., Bex, V., and Midgley P. M., (eds.)]. Cambridge University Press, Cambridge, United Kingdom and New York, NY, USA, 1535 pp., doi: 10.1017/CBO9781107415324.

Klein Tank, A. M. G., Peterson, T. C., Quadir, D. A., Dorji, S., Zou, X., Tang, H., Santhosh, K., Joshi, U. R., Jaswal, A. K., Kolli, R. K., Sikder, A. B., Deshpande, N. R., Revadekar, J. V., Yeleuova, K., Vandasheva, S., Faleyeva, M., Gomboluudev, P., Budhathoki, K. P., Hussain, A., Afzaal, M., Chandrapala, L., Anvar, H., Amanmurad, D., Asanova, V. S., Jones, P. D., New, M. G., and Spektorman, T., 2006. Changes in daily temperature and precipitation extremes in central and south Asia. Journal of Geophysical Research, Vol 111, 18 .

Krol, M., Bronstert, A., Jaeger, A., Gunter, A., Hauschild, M., and Doll, P., 2000. Integrated modelling of water availability and water use in the semi-arid Northeast of Brazil. Science Direct, 25(3), 227-232.

Lal, R., Delgoda, J. A., Groffman, P. M., Milar, N., Dell, C., and Rotz, A., 2011. Management to Mitigate and Adapt to Climate Change. Journal of Soil and Water Conservation, 66(No. 04).

Mahmood, R., \& Babel, M. S. (2012). Evaluation of SDSM developed by annual and monthly sub-models for downscaling temperature and precipitation in the Jhelum basin, Pakistan and India. Theoretical and Applied Climatology - Springer, 113(1-2), 27-44.

Mahmood, R., Babel, M. S., and Shaofeng, J. A., 2015. Assessment of temporal and spatial changes of future climate in the Jhelum river basin, Pakistan and India. Elsevier, 10, 40-55.

Patabandige, C. S., Kazama, S., and Komori, D., 2016. Near future climatic impact on seasonal runoff in Sri Lanka. Research Gate.

Salzmann, N., Frei, C., Vidale, P., and Hoelzle, M., 2007. The application of Regional Climate Model output for the simulation of high-mountain permafrost scenarios. Global and Planetary Change - Elsevier, 56, 188-202.

Stem, N., 2007, The economics of climate change: the stern review. Cambridge University Press, Cambridge, 692.

Wetterhall, F., Bárdossy, A., Chen, D., Halldin, S., and Xu, C., 2008. Statistical downscaling of daily precipitation over Sweden using GCM output. Theoretical Applied Climatology - Springer, 1-9.

Wetterhall, F., Halldin, S., and Xu, C., 2004. Statistical precipitation downscaling in central Sweden with the analogue method. Journal of Hydrology - Elsevier, 306 (2005), 174-190.

Wilby, R. L., and Wigley, T. M. L., 2000. Precipitation predictors for downscaling: observed and General Circulation Model relationship. International Journal of Climatology, 20, 641-661.

Wilby, R. L., Whitehead, P. G., Wade, A. J., Butterfield, D., Davis, R. J., and Watts, G., 2006. Integrated modelling of climate change impacts on water resources and quality in a lowland catchment: River Kennet, UK. Elsevier, 330, 204-220. 

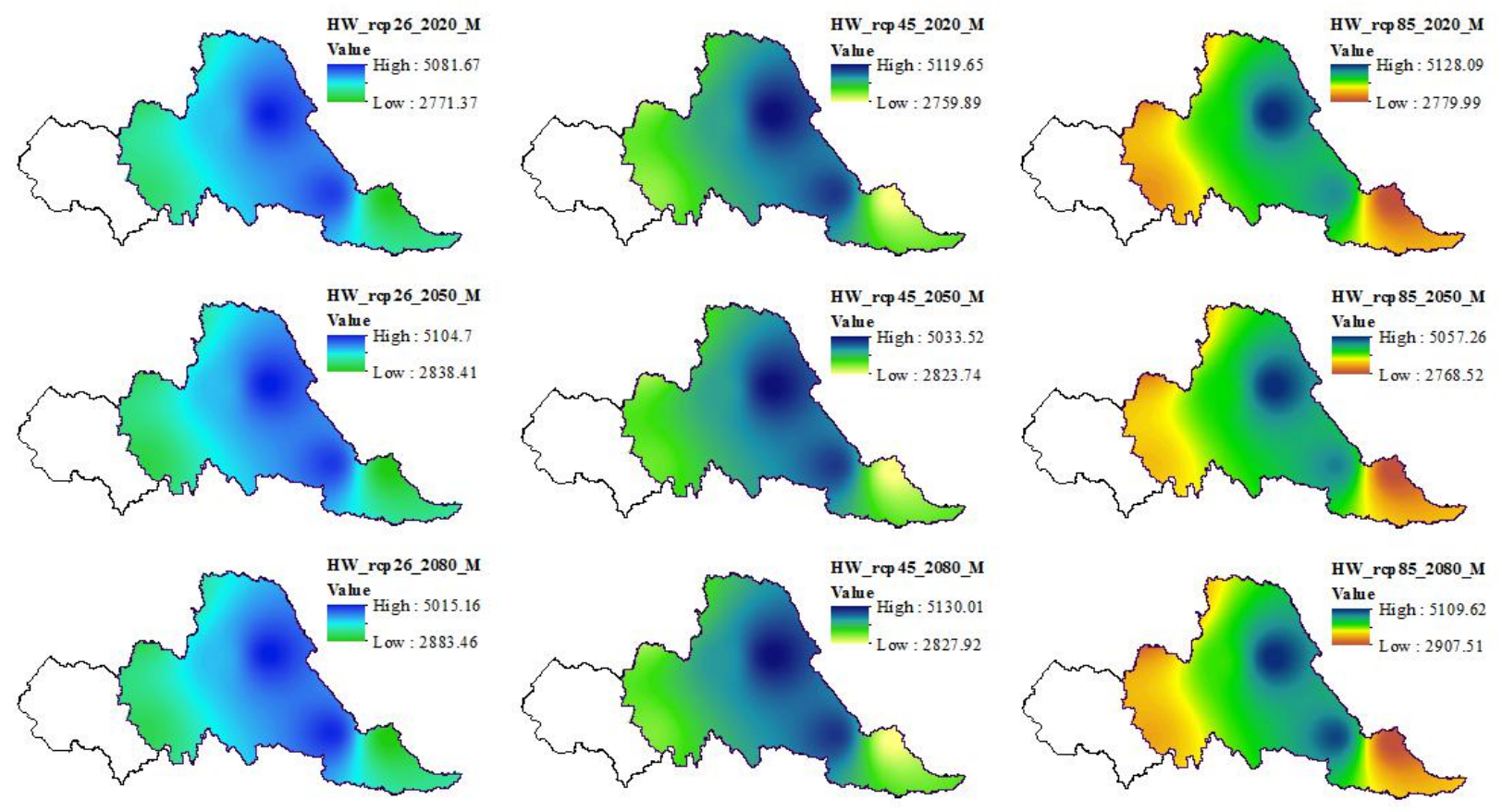

Hanwella_Watershed

Kelani_Ganga_River_Basin

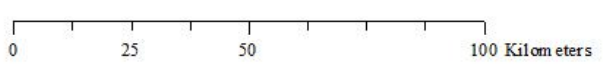

Figure A.l Future Precipitation Variation in Hanwella watershed by monthly sub-model for 2020s, 2050s and 2080s periods
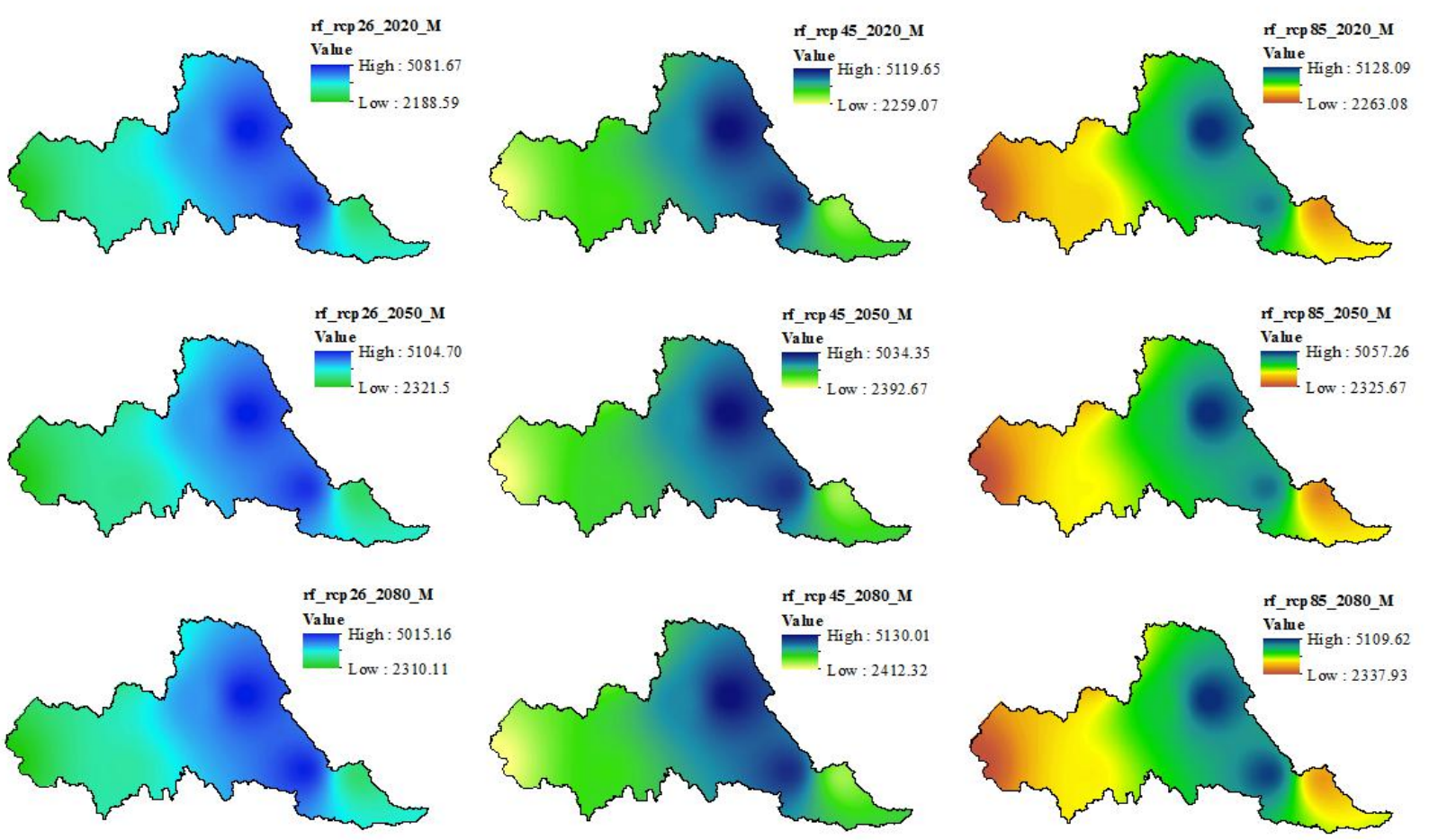

Kelani_Ganga_River_Basin

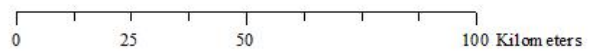

Figure A.2 Future Precipitation Variation in Hanwella watershed by monthly sub-model for 2020s, 2050s and 2080s periods 

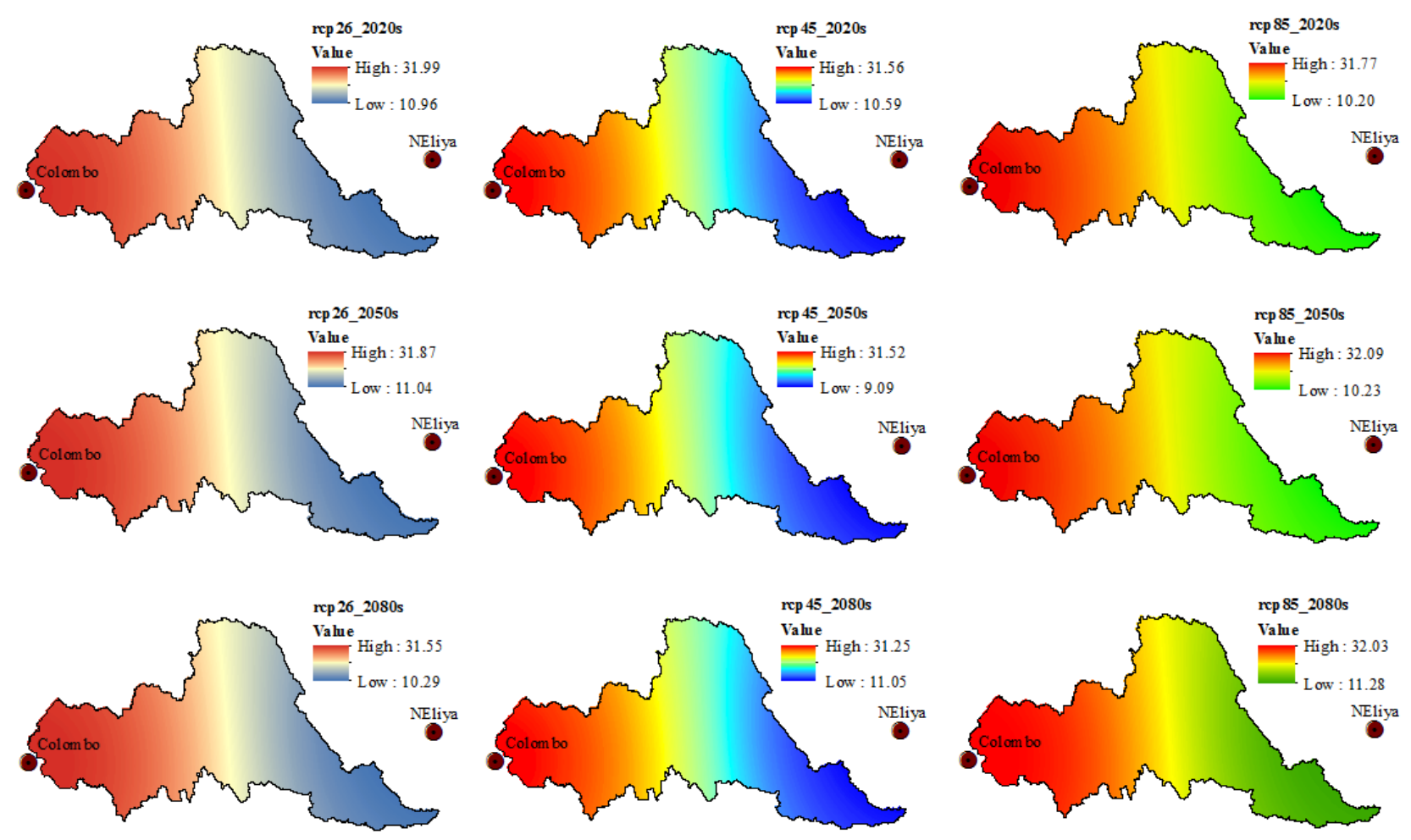

- Temperature_gauging_stations

Kelani_Ganga_River_Basin

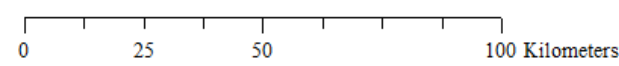

Figure A.3 Future Temperature variation in Kelani River basin by monthly sub-model for 2020s, 2050s and 2080 s periods 